Arch. Tierz., Dummerstorf 44 (2001) 6, 579-587

Institute of Animal Breeding and Husbandry, Christian-Albrechts-University of Kiel, Germany

RAINER RÖHE, TÖRKER SAVAS, MUHAMED BRKA, FRIEDRICH WILLMS and BRNST KALM

\title{
Multiple-trait genetic analyses of racing performances of German trotters with disentanglement of genetic and driver effects
}

\author{
Dedicated to Prof. Dr. Dr, h, c. Hans Joachim Schwark on the occasion of \\ his $75^{\text {th }}$ birthday
}

\begin{abstract}
Summary
The objectives of this study were the analysis of the effect of driver on racing performances of trotters and development of a genetic model in order to estimate genetic parameters for German trotters. Data on 6,611 trotters with 163,322 records during 1997 and 1999 were analysed with a repeatability animal model using each individual start of trotters and pedigree information of up to 11 generations (13,202 horses). Besides the driver effect, the genetic model included year-season, age and sex of trotter, racing track, distance and condition of race track as fixed effects as well as additive genetic and permanent environmental effects as random effects. Traits analysed were square root of rank at finish, racing time per $\mathrm{km}$ and the logarithms of earnings per start. Ignoring the effect of driver resulted in an overestimation of heritability of 60,24 and $44 \%$ for rank at finish, racing time and earnings, respectively, which shows the necessity to include the driver effect in the model. Drivers regarded as fixed or random effects resulted in a marginal change in parameters. Heritabilities based on the model with fixed driver effect were $0.05,0.29$ and 0.09 for ranks at finish, racing time and earnings, respectively. Genetic correlation between rank and racing time was 0.81 . Both traits were highly correlated with earnings of -0.98 and -0.89 for ranking and racing time, respectively. Most important trait for selection of racing performance was the racing time due to its substantial higher heritability and its high genetic correlation to earnings. Additionally, rank at finish has to be included in the breeding goal because it reflects more the potential of trotters to win at finish and accounts for records without earnings.
\end{abstract}

Key Words: animal model, heritability, genetic correlation, racing performance, trotter, horses

\section{Zusammenfassung}

Titel der Arbeit: Multivariate Analyse von Rennleistungen von Deutschen Trabern mit besonderer Bericksichtigung der Trennung der Genetik vom Fahrereinfluss

Das Ziel der Untersuchung lag in der Analyse der Bedeutung des Fahrereffektes auf die Rennleistungen und der Entwicklung eines genetischen Modells, um die genetischen Parameter von Deutschen Trabern zu schătzen. Das Datenmaterial setzte sich aus 6.611 Trabern mit 163.322 Rennleistungen wăhrend der Jahre 1997 bis 1999 zusammen. Die Analyse erfolgte auf der Basis eines Tiermodells, in dem alle individuellen Starts als wiederholte Leistungen Berucksichtigung fanden. Das genetische Modell berucksichtigte neben dem Fahrereffekt die fixen Effekte der Jahres-Saison, Alter, Geschlecht, Rennbahn, Distanz, Zustand der Bahn und die zufalligen genetischen und permanent umweltbedingten Effekte. Als Merkmale wurden die Quadratwurzel der Platzziffer, die Rennzeit pro $\mathrm{km}$ und der Logarithmus der Gewinnsumme verwandt. Die Nichtberucksichtigung des Fahrereffektes im Modell resultierte in einer Überschaltzung der Heritabilităt von 60,24 und $44 \%$ fur die Platzziffer, Rennzeit und Gewinnsumme. Alternative Analysen des Fahrers als fixer oder zufalliger Effekt beeinflussten die genetischen Parameter kaum. Die geschatzten Heritabilitaten der Merkmale Platzziffer, Rennzeit und Gewinnsumme betrugen 0,05, 0,29 und 0,09. Fur Platzziffer und Rennzeit wurde eine genetische Korrelation von 0,81 geschallzt und beide Merkmale zeigten eine sehr enge genetische Beziehung zur Gewinnsumme von $-0,98$ und $-0,89$. Als bedeutendstes Rennleistungsmerkmal erwies sich die Rennzeit, die die höchste Heritabilităt aller Merkmale erzielte und eine sehr enge genetische Korrelation zur Gewinnsumme zeigte. Zustlzlich sollte die Platzziffer als Zuchtwertmerkmal verwandt werden, da diese eng mit dem 
genetischen Leistungspotential der Traber im Finish verbunden ist und gleichzeitig die Rănge der Pferde ohne Gewinnsumme berucksichtigt.

Schlüsselwörter: Tiermodell, Heritabilität, genetische Korrelation, Rennleistung, Traber, Pferde

1. Introduction

Estimation of breeding values of German trotters was based on a sire model using traits such as average racing time per year and money earnings per year (KATONA and DISTL, 1989; SCHMITT, 1996). However, the BLUP animal model using all genetic relationships among animals has much more desirable statistical and genetic properties (KENNEDY et al., 1988) and therefore, should be used as standard method for estimation of breeding values. For Swedish standardbred trotters, the BLUP animal model has already been introduced in 1992 and an official publication of a BLUP animal index has been proven as effective selection criterion (ÁRNASON, 1997; ÁRNASON, 1999).

In several genetic evaluation procedures in Europe, racing performances are accumulated over the year and then annual records are used for estimation of breeding values (e.g. LANGLOIS et al., 1997; ÁRNASON, 1999). However, using individual race information, environmental effects can be estimated much more accurately and information of each record will be appropriately weighted in the final breeding value. That means, based on individual racing records, track conditions at each single record can be estimated directly and no pre-adjustment of records for these effects is necessary, as used in the former genetic evaluation procedure in Germany. Additionally, a permanent environmental effect can be estimated, which results in a direct disentanglement of random genetic and environmental effects of repeated records of each horse. Also, the driver can be estimated based on individual records of trotters. The main problem of estimation of this effect is its close confounding to genetic effects. Therefore, the distribution of horses per driver and vice versa is an important indicator for disentanglement of driver and genetic effects. Furthermore, the driver effect can be considered differently as random or fixed effect in the geneticstatistical model.

Racing performances such as rank at finish, racing time and earnings are very often highly, genetically associated among each other. As a consequence, breeding values estimated on a multiple-trait animal model have to be used in order to make accurate selection decisions based on these traits. For the animal BLUP evaluation, genetic parameters estimated on the same population and based on the same genetic model are necessary in order to avoid biased breeding values due to under- or overestimated genetic parameters.

Consequently, the objectives of this study were (1) creation of an appropriate genetic statistical model for evaluation of breeding values, (2) comparison of different genetic statistical models regarding the driver effect as fixed or random as well as ignoring this effect and (3) estimation of genetic parameters for the German trotter population using the most appropriate multiple-trait animal model.

2. Materials and methods

Since 1973 individual racing performances have been recorded at Hauptverband furr Traber-Zucht und -Rennen e. V. in Germany. Data of the present analyses consisted of 
22,846 races from 6,611 trotters with records from 1997 to 1999 . In this data, only races with more than 4 starters were considered and drivers had to have at least 5 starts. Starting method was in all races the auto start also known as flying start behind a car.

In total, data on 163,322 individual race performances were used in these analyses. Distribution of starts per horse and the number of progeny per sire or dam are presented in Table 1. The highest frequency group of starts per horse showed 11 to 20 starts, which was lower than the average of 24.7 starts per horse. This shows that the distribution is positively skewed and indicates that a few number of horses had a high number of starts. The 6,611 trotters with records was progeny of 679 sires and 3,799 dams. Average number of progeny per sire were 9.7, and thus, above the highest frequency group of 2 to 5 progeny per sire, indicating that few sires w-re used frequently for breeding. The average number of progeny per dam was 1.7 and $59 \%$ of the dams had only one progeny in the analysed data. The pedigree of each racing horse was traced back to the 11. generation so that in total 13,202 horses were used in this study.

\section{Table I}

Frequencies of starts per horse, progeny per sire, and progeny pe: dam of 6,611 trotters with performance records from 1997 to 1999 (Häufigkeitsverteilung der Starts je Pferd, Nachkommen je Vater und Nachkommen je Multer fuir 6.611 Traber mit Leistungsinformationen in den Jahren 1997 bis 1999)

\begin{tabular}{|c|c|c|c|c|c|c|}
\hline \multirow[b]{2}{*}{ Group } & \multicolumn{2}{|c|}{ Frequency of starts per horse } & \multicolumn{2}{|c|}{ Frequency of progeny per sire } & \multicolumn{2}{|c|}{ Frequency of progeny per dam } \\
\hline & Starts / horse & No, of horses & Progeny / sire & No, of sires & Progeny / dam & No. of dams \\
\hline 1 & $1-5$ & $185(3 \%)$ & 1 & $181(27 \%)$ & 1 & $2242(59 \%)$ \\
\hline 2 & $6-10$ & $914(14 \%)$ & $2-5$ & $248(36 \%)$ & 2 & $997(26 \%)$ \\
\hline 3 & $11-20$ & $2098(32 \%)$ & $6-10$ & $100(15 \%)$ & 3 & $394(10 \%)$ \\
\hline 4 & $21-30$ & $1417(21 \%)$ & $11-20$ & $70(10 \%)$ & 4 & $134(4 \%)$ \\
\hline 5 & $31-40$ & $953(14 \%)$ & $21-30$ & $35-54$ & 5 & $26(0.7 \%)$ \\
\hline 6 & $>40$ & $1044(16 \%)$ & $>30$ & $45(7 \%)$ & $>6$ & $6(0.2 \%)$ \\
\hline Total & & 6611 & & 679 & & 3799 \\
\hline
\end{tabular}

Table 2

Means $(\bar{x})$, standard deviations (s) and coefficients of variation (CV) for analysed racing performances (Mittelwerte $(\vec{x})$, Standardabweichungen (s) und Variationskoeffizienten fur die analysierten Rennleistungsmerkmale)

\begin{tabular}{lcccc}
\hline Trait & $\mathrm{N}$ & $\bar{x}$ & $\mathrm{~s}$ & $\mathrm{CV}(\%)$ \\
\hline Rank at finish $(\sqrt{y})$ & 163322 & 1.999 & 0.598 & 30 \\
Racing time $(\mathrm{s} / \mathrm{km})$ & 163322 & 79.89 & 2,25 & 3 \\
Earnings $(\log \mathrm{y})$ & 112045 & 2.769 & 0.421 & 15 \\
Eamings $(\mathrm{DM})$ & 112045 & 1043 & 3130 & 300 \\
\hline
\end{tabular}

Traits analysed were rank at finish, racing time per $\mathrm{km}$, and earnings per race. In order to achieve a reasonable approximation to the normal distribution, rank at finish was transformed by its square root and for earnings the log transformation was used. Observations with zero earnings were treated as missing values. Means of the traits are presented in Table 2. High positive skewness of earnings per race in German Marks 
resulted in a large coefficient of variation of $300 \%$, which decreased substantially to $15 \%$ when using log transformation.

Variance components were estimated using REML procedure as implemented in the program VCE (NEUMAIER and GROENEVELD, 1998). The following three different genetic-statistical models were used:

$$
\mathbf{y}=\mathbf{x b}+\mathbf{z}_{1} \mathbf{a}+\mathbf{z}_{2} \mathbf{p e}+\mathbf{e},
$$

where $\mathbf{y}$ is the vector of observations containing the traits of each trotter recorded at each individual race as square root of rank at finish, racing time per $\mathrm{km}$ and the log of earnings per start. Vector $\mathbf{b}$ represents the fixed effect including the effect of yearseason of race (two months were combined to one season), age of trotter (age classes of $2, \ldots, 10$ and $>10$ years old trotters), sex (stallion, mare, gelding), race track (restricted to 13 major race tracks), distance of race $(1600,1700,1800,1900,2000$, $2100,2500,2600 \mathrm{~m}$ ), condition of the race track (fast, good, medium, heavy, muddy). The vector a represents the random additive genetic effects assumed to be distributed as $N(0, \mathbf{G} \otimes \mathbf{A})$, where $\mathbf{G}$ is the additive genetic variance-covariance matrix among traits, and $\mathbf{A}$ is the additive genetic relationship matrix among horses, and the $\otimes$ denotes the Kronecker product between these matrices. Permanent environmental effects are estimated as random effect vector pe and are assumed to be distributed as $N(\mathbf{0}, \mathbf{P E} \otimes \mathbf{I})$, where $\mathbf{P E}$ is the permanent environmental variance-covariance matrix among traits and $\mathbf{I}$ is the identity matrix. Vector e refers to the residual effects and is distributed as $N(\mathbf{0}, \mathbf{R} \otimes \mathbf{I})$, where $\mathbf{R}$ is the residual variance-covariance matrix among traits. The known incidence matrices $\mathbf{X}, \mathbf{Z}_{1}, \mathbf{Z}_{2}$ relate the observations to corresponding fixed and random effects levels.

The second model was:

$$
\mathbf{y}=\mathbf{X b}+\mathbf{Z}_{1} \mathbf{a}+\mathbf{Z}_{2} \mathbf{p e}+\mathbf{Z}_{3} \mathbf{d r}+\mathbf{e}
$$

which additionally includes drivers as random effect vector $\mathbf{d r}$. Matrix $\mathbf{Z}_{3}$ denotes the known incidence matrix of the driver effect. The distribution of the random driver effect is assumed to be distributed as $N(\mathbf{0}, \mathbf{D R} \otimes \mathbf{I})$, where $\mathbf{D R}$ denotes the variancecovariance matrix among traits due to drivers.

The third model treated the driver as fixed effect so that the model changed to:

$$
\mathbf{y}=\mathbf{x}_{1} \mathbf{b}+\mathbf{X}_{2} \mathrm{dr}+\mathbf{Z}_{1} \mathbf{a}+\mathbf{Z}_{2} \mathbf{p e}+\mathrm{e},
$$

where $\mathbf{X}_{\mathbf{2}}$ is the incidence matrix of the fixed driver effect $\mathbf{d r}$.

For estimation of the driver effect, the use of different horses by each driver is necessary. Distribution of horses per driver and drivers per horse is given in Table 3 . There were only $6 \%$ of drivers, who drove only one horse. About $10 \%$ of the drivers had even driven more than 50 horses and $7 \%$ of the horses were driven by 11 to 24 drivers. This high number of exchange of horses by drivers allows to estimate the driver effect directly in the statistical model.

\section{3.} Results and discussion

Racing time per $\mathrm{km}$ improved by $3 \mathrm{~s}$ when age of trotters increased from 2 to 9 years. Stallions were 0.8 and $0.7 \mathrm{~s} / \mathrm{km}$ faster than mares and geldings. Condition of the racing track resulted in a difference racing time of $2.1 \mathrm{~s} / \mathrm{km}$ between fast and heavy assessed 
track. However, race track condition showed only an influence on the racing time per $\mathrm{km}$ and not on rank at finish and earnings per start. The other fixed effects, such as year-season, age of trotters, sex, racing track and distance were significant for all traits. These effects were also found significant by KATONA and DISTL (1989) estimated on an earlier data set of German trotters.

Table 3

Frequencies of horses per driver and drivers per horse of 6,611 trotters with performance records from 1997 to 1999 (Häufigkeitsverteilung der Pferde je Fahrer und der Fahrer je Pferd fur 6.611 Traber mit Leistungsinformationen in den Jahren 1997 bis 1999)

\begin{tabular}{lcccc}
\hline & \multicolumn{2}{c}{ Frequency of horses per driver } & Frequency of drivers per horse \\
Group & Horses / driver & Number of drivers & Drivers / horse & Number of horses \\
\hline 1 & 1 & $96(6 \%)$ & 1 & $611(9 \%)$ \\
2 & $2-5$ & $568(37 \%)$ & 2 & $975(15 \%)$ \\
3 & $6-15$ & $434(28 \%)$ & $3-4$ & $1933(29 \%)$ \\
4 & $16-50$ & $292(19 \%)$ & $5-6$ & $1379(21 \%)$ \\
5 & $51-100$ & $98(6 \%)$ & $7-10$ & $1257(19 \%)$ \\
6 & $>100$ & $58(4 \%)$ & $11-24$ & $456(7 \%)$ \\
\hline Total & \multicolumn{5}{c}{} \\
\hline
\end{tabular}

Table 4

Additive genetic (a), permanent environmental (pe) and residual (e) variances or parameters for racing performances without considering the driver effect in the statistical model (Genetische (a), permanent umweltbedingte (pe) und residuale (e) Varianzen oder Parameter filr die Rennleistungsmerkmale ohne Berlucksichtigung des Fahrereffektes im statistischen Modell)

\begin{tabular}{lccccc}
\hline Trait & $\sigma_{\mathrm{a}}{ }^{2}$ & $\sigma_{\rho \mathrm{e}}{ }^{2}$ & $\sigma_{\mathrm{e}}{ }^{2}$ & $\mathrm{~h}^{2}$ & $\mathrm{pe}^{2}$ \\
\hline Rank at finish $(\sqrt{y})$ & 0.038 & 0.041 & 0.376 & $0.08(.006)$ & $0.09(.004)$ \\
Racing time $(\mathrm{s} / \mathrm{km})$ & 1.122 & 0.504 & 1.474 & $0.36(.017)$ & $0.16(.014)$ \\
Earnings (log y) & 0.041 & 0.034 & 0.242 & $0.13(.008)$ & $0.11(.006)$ \\
\hline Standard errors in parenthesis & & & & &
\end{tabular}

Standard errors in parenthesis

Table 5

Genetic $(\mathrm{g})$, permanent environmental (pe) and phenotypic $(\mathrm{p})$ correlations $(\mathrm{r}$ ) between racing performances without considering the driver effect in the statistical model (Genetische (a) und phanotypische (p) Korrelationen (r) zwischen Rennleistungsmerkmalen ohne Ber(lcksichtigung des Fahrereffektes im statistischen Modell)

\begin{tabular}{lccccccc}
\hline Trait & \multicolumn{3}{c}{ Racing time $(\mathrm{s} / \mathrm{km})$} & \multicolumn{3}{c}{ Earnings $(\log y)$} \\
& $\mathrm{r}_{\mathrm{B}}$ & $\mathrm{r}_{\mathrm{pe}}$ & $\mathrm{r}_{\mathrm{p}}$ & $\mathrm{r}_{\mathrm{B}}$ & $\mathrm{r}_{\mathrm{pe}}$ & $\mathrm{r}_{\mathrm{p}}$ \\
\hline Rank at finish $(\sqrt{y})$ & $0.85(.025)$ & $0.66(.024)$ & 0.40 & $-0.97(.009)$ & $-0.83(.011)$ & -0.59 \\
Racing time $(\mathrm{s} / \mathrm{km})$ & & & & $-0.92(.015)$ & $-0.68(.023)$ & -0.42 \\
\hline Standard erros in parenthesis & & & &
\end{tabular}

Standard errors in parenthesis

At first, variance components were estimated by ignoring the driver effect in the genetic statistical model (Tables 4 and 5). Racing time per $\mathrm{km}$ showed about 3 to 4.5 times higher heritability than earnings and rank at finish, respectively. Proportion of the permanent environmental variance on the phenotypic variance showed an almost equal magnitude than heritabilities for traits such as rank at finish and earnings but a substantially lower magnitude for racing time. Very high genetic correlations $(>-0.9)$ were obtained between rank at finish as well as racing time and earnings per start. 
Genetic correlation was less than 0.9 between rank at finish and racing time. Estimates of genetic correlations and heritabilities showed low standard errors, indicating the high amount of informative data available in this study.

Variance components and their phenotypic ratios, regarding driver effect as random are presented in Tables 6 and 7. In comparison with estimates when the driver effect was ignored (Tables 4 and 5), heritabilities decreased by 25,22 and $31 \%$ for rank at finish, racing time and earnings, respectively. The reduction is mainly due to a decline in additive genetic variance by 34,23 and $32 \%$ for the same traits. Phenotypic fraction of permanent environmental variance decreased only little for rank at finish and earnings per start or even increased for racing time. Genetic and permanent environmental correlations between rank at finish and racing time decreased from 0.85 to 0.80 and from 0.66 to 0.62 when the driver effect was considered, whereas correlations of these traits with earnings did hardly change.

Table 6

Additive genetic (a), permanent environmental (pe), driver influenced (dr), and residual (e) variances or parameters for racing performances considering driver as a random effect in the statistical model (Genetische (a), permanent umweltbedingte (pe), fahrerbeeinflusste (dr) und residuale (e) Varianzen oder Parameter für die Rennleistungsmerkmale unter Berucksichtigung eines zufalligen Fahrereffektes im statistischen Modell)

\begin{tabular}{lccccccc}
\hline Trait & $\sigma_{\mathrm{a}}{ }^{2}$ & $\sigma_{\mathrm{pe}}{ }^{2}$ & $\sigma_{\mathrm{dr}}{ }^{2}$ & $\sigma_{\mathrm{c}}{ }^{2}$ & $\mathrm{~h}^{2}$ & $\mathrm{pe}^{2}$ & $\mathrm{dr}^{2}$ \\
\hline Rank at finish $(\sqrt{y})$ & 0.025 & 0.035 & 0.019 & 0.368 & $0.06(.004)$ & $0.08(.004)$ & $0.04(.002)$ \\
Racing time $(\mathrm{s} / \mathrm{km})$ & 0.859 & 0.522 & 0.245 & 1.402 & $0.28(.014)$ & $0.17(.012)$ & $0.08(.003)$ \\
Earnings (log y) & 0.028 & 0.031 & 0.010 & 0.238 & $0.09(.006)$ & $0.10(.005)$ & $0.03(.002)$ \\
\hline
\end{tabular}

Standard errors in parenthesis

Table 7

Genctic (g), permanent environmental (pe), driver influenced (dr) and phenotypic (p) correlations ( $r$ ) between racing performances considering driver as a random effect in the statistical model (Genetische (a) und phänotypische ( $\mathrm{p}$ ) Korrelationen $(\mathrm{r})$ zwischen Rennleistungsmerkmalen unter Berälksichtigung eines zufalligen Fahrereffektes im statistischen Modell)

\begin{tabular}{lcccc}
\hline Trait & \multicolumn{2}{c}{ Racing time $(\mathrm{s} / \mathrm{km})$} & \multicolumn{2}{c}{ Earnings $(\log \mathrm{y})$} \\
& $\mathrm{r}_{\mathrm{g}}$ & $\mathrm{r}_{\mathrm{p}}$ & $\mathrm{r}_{\mathrm{z}}$ & $\mathrm{r}_{\mathrm{p}}$ \\
\hline Rank at finish $(\sqrt{y})$ & $0.80(.026)$ & 0.38 & $-0.96(.010)$ & -0.58 \\
Racing time $(\mathrm{s} / \mathrm{km})$ & & & $-0.89(.015)$ & -0.39 \\
& $\mathrm{r}_{\mathrm{dr}}$ & $\mathrm{r}_{\mathrm{ps}}$ & $\mathrm{r}_{\mathrm{dr}}$ & $\mathrm{r}_{\mathrm{ps}}$ \\
\hline Rank at finish $(\sqrt{y})$ & $0.70(.016)$ & $0.62(.025)$ & $-0.78(.017)$ & $-0.83(.011)$ \\
Racing time $(\mathrm{s} / \mathrm{km})$ & & & $-0.80(.016)$ & $-0.67(.022)$ \\
\hline
\end{tabular}

The severe overestimation of heritabilities when ignoring the driver effect showed the importance to account for this effect in the genetic model. Although genetic correlations were barely influence is ignoring the driver effect, in particular the reduced correlation between rank at fimiss and racing time is important for the decision whether to use both or one trait in the breeding goal. THUNEBERG-SELONEN et al. (1999) considered the driver indirectly by 7 classes depending on the number of starts per driver. In their study, a direct consideration of driver effect in the model inflated the variance components due to confounding of driver, additive genetic and permanent environmental effects. In the present study, there was no such inflation of variance components, which indicates a sufficient exchange of horses by drivers in order to disentangle these effects. 
HENDERSON (1973) suggested that environmental effects not distributed randomly over the genetic potential of animals should be regarded as fixed in order to avoid biased breeding values. Therefore, assuming that drivers were not randomly distributed over the genetic potential of trotters, i.e. best horses are assigned to the best drivers and vice versa, this effect should be regarded as fixed in order to avoid biased breeding values. Genetic and environmental variance components and their phenotypic fraction as well as correlations when regarding the driver effect as fixed in the model are presented in Tables 8 and 9. Comparing estimates using driver effects as random or fixed showed barely any difference in magnitude. Only a small reduction in additive genetic variance, when using driver as fixed, may be mentioned. Also, it is interesting that the genetic correlation between rank at finish and earnings per start approached almost unity $\left(\mathrm{r}_{\mathrm{g}}=-0.98\right)$ when using driver as fixed.

Genetic parameters estimated based on comparable analyses, i.e. using records of individual races within a repeatability animal model were reported by KOERHUIS and SCHEPERS (1998) and THUNEBERG-SELONEN et al. (1999). These authors estimated heritabilities for racing time in the range of $h^{2}=0.23$ to 0.31 , which is in agreement with the estimate obtained in the present study $\left(\mathrm{h}^{2}=0.29\right)$. THUNEBERGSELONEN et al. (1999) found a higher estimate $\left(h^{2}=0.12\right)$ for rank at finish compared to the present study $\left(\mathrm{h}^{2}=0.05\right)$. For earnings, THUNEBERG-SELONEN et al. (1999) presented a similar heritability $\left(h^{2}=0.09\right)$ for standardbred trotters, but lower for Finnhorses with $h^{2}=0.05$. Estimates based on single racing information were generally lower than the estimates based on annual accumulated records, which may indicate the overestimation of parameters when those records were used. Based on individual racing records, estimates of genetic correlations among the analysed performance traits were not available in the literature.

Table 8

Additive genetic (a), permanent environmental (pe) and residual (e) variances or parameters for racing performances considering driver as a fixed effect in the statistical model (Genetische (a), permanent umweltbedingte (pe) und residuale (e) Varianzen oder Parameter fur die Rennleistungsinerkmale unter Berllcksichtigung eines zufalligen Fahrereffektes im statistischen Modell)

\begin{tabular}{lccccc}
\hline Trait & $\sigma_{a}{ }^{2}$ & $\sigma_{p c}{ }^{2}$ & $\sigma_{c}{ }^{2}$ & $\mathrm{~h}^{2}$ & $\mathrm{pe}^{2}$ \\
\hline Rank at finish $(\sqrt{y})$ & 0.023 & 0.035 & 0.368 & $0.05(.004)$ & $0.08(.004)$ \\
Racing time $(\mathrm{s} / \mathrm{km})$ & 0.780 & 0.537 & 1.400 & $0.29(.015)$ & $0.20(.012)$ \\
Eamings $(\log \mathrm{y})$ & 0.026 & 0.031 & 0.239 & $0.09(.006)$ & $0.10(.005)$ \\
\hline
\end{tabular}

Table 9

Genetic $(\mathrm{g})$, permanent environmental and phenotypic $(\mathrm{p})$ correlations $(\mathrm{r}$ ) between racing performances considering driver as a fixed effect in the statistical model (Genetische (a) und phanotypische (p) Konrelationen (r) zwischen Rennleistungsmerkmalen unter Berucksichtigung eines fixen Fahrereffektes im statistischen Modell)

\begin{tabular}{|c|c|c|c|c|c|c|}
\hline \multirow[t]{2}{*}{ Trait } & \multicolumn{3}{|c|}{ Racing time $(\mathrm{s} / \mathrm{km})$} & \multicolumn{3}{|c|}{ Earnings (log y) } \\
\hline & $r_{R}$ & $\mathbf{r}_{p e}$ & $r_{p}$ & $\mathbf{r}_{B}$ & $\mathbf{r}_{\mathrm{Bs}}$ & $\mathrm{r}_{\mathrm{p}}$ \\
\hline Rank at finish $(\sqrt{y})$ & $0.81(.025)$ & $0.58(.024)$ & 0.35 & $-0.98(.009)$ & $-0.84(.010)$ & -0.57 \\
\hline Racing time (s/km) & & & & $-0.89(.015)$ & $-0.66(.021)$ & -0.36 \\
\hline
\end{tabular}

4. Conclusions

Based on the present results it can be concluded that the driver effect has to be considered in the statistical model in order to avoid overestimation of breeding values 
due to overestimated heritabilities. In order to avoid possible bias in estimation of breeding values due to preferable designation of best horses to best driver, the driver effects should be treated as fixed in the genetic model. The most important trait for selection is racing time per $\mathrm{km}$ because it showed the highest heritability $\left(\mathrm{h}^{2}=0.29\right)$ of all analysed racing performances, it was highly correlated to the economically important trait earnings, it reasonably approximated the normal distribution without transformation, and it allows to monitor genetic trend. Rank at finish and racing time showed an important deviation from unity, indicating that these traits have different genetic basis. This may be due to the fact that rank at finish more closely measures the ability of the horse to win the finish, whereas racing time is more associated with speed over the entire distance and reflects more the endurance of the horse. Therefore, at least these two traits should be included in the breeding goal. Both traits are highly correlated with the earnings per start so that selection will result directly in high economic response. In comparison to rank at finish, a direct selection on earnings results in a high loss of information because trotters without earnings are not considered. HASSENSTEIN et al. (1999) showed that square root of rank had not only desirable statistical properties in order to approach normality and to be more independent from the number of starts, but also resulted in the desirable property to weight first ranks exponentially higher than lower ranks, which corresponds with their economic values. This can be confirmed by the very high genetic correlation between square root of rank at finish and earnings per start, which approached unity $\left(r_{\mathrm{g}}=-0.98\right)$. The only reason to include log earnings into the breeding goal is its higher heritability $\left(h^{2}=0.09\right)$ compared to rank at finish $\left(h^{2}=0.05\right)$.

There may be further traits included in the breeding goal, which were not considered in the present study. For example, information of non-finished or disqualified races should be considered in the genetic evaluation. KOERHUIS and SCHEPERS (1998) analysed the percentage of races not finished as a separate trait. KATONA and DISTL (1989) considered non-finished races of trotters indirectly by zero earnings. Preliminary studies in our data showed a substantially decrease in heritability of log earnings when zero values were included. This may also be the reason for a low heritability of earnings estimated by THUNEBERG-SELONEN et al. (1999) for Finnhorses. Therefore, the use of a separate trait for non-finished races may be more efficient to improve component traits like temperament, endurance and regularity of gait. Furthermore, KLEMETSDAL (1992) showed that offspring not used for racing (non-starters) can result in substantial bias in estimation of breeding values of parents due to pre-selection. Therefore, an additional trait like start status ( 0 for non-starter and 1 for starter) as used in the genetic evaluation procedure in Sweden may remove bias due to pre-selection (ÁRNASON, 1999). Also, traits associated with health, confirmation and precocity should be added to the breeding objective (SAASTAMOINEN, 1997; WILLMS et al., 1999).

\section{ARNASON, T.:}

\section{References}

Genetic evaluation of Swedish standard-bred trotters for racing performance traits and racing status. J. Anim. Breed. Genet. 116 (1999), 387-398

ARNASON, T.:

The selection intensity in standardbred trotters in Sweden as measured by BLUP animal model index. In: Book of Abstracts $48^{\text {th }}$ Annual Meeting EAAP, Vienna, Austria, Wageningen Pers (1997), p 380 
HASSENSTEIN, C.; ROHE, R.; KALM, E.:

Genetisch statistische Analyse von neuentwickelten Merkmalen aus Tumiersportprufungen für Reitpferde. 1. Mitteilung: Merkmalsentwicklung und Heritabilitătsschătzung. Zuchtungskunde, Stuttgart 71 (1999), 106-117

HENDERSON, C. R.:

Sire evaluation and genetic trends. Proc. Anim. Breed, Genet. Symp. in honor of J. L. Lush., KATONA, Ö; DISTL, O.:

Sire evaluation in the German trotter (Standardbred) population. In: LANGLOIS, B. (ed.). State of breeding evaluation in trotters. EAAP Publication No. 42, Wageningen Pers, Wageningen. (1989), 55 -

KENNEDY, B.W.; SCHAEFFER, L.R.; SÖRENSEN, D.A.::

Genetic properties of animal models. J. Dairy Sci. (suppl. 2) 71 (1988), $17-26$

KLEMETSDAL, G.:

Estimation of genetic trends in racehorse breeding. Acta Agric. Scand. 42 (1992), 226-231

KOERHUIS; A.N.M.; SCHEPERS, A. J.: Genetische Analyse van Kilometertijd voor de Nederlandse Populatie van Dravers. Diplona theses,
Wageningen, The Netherlands (1998)

LANGLOIS, B.; BLOUIN, C.; RICARD, A.:

Global Efficiency of BLUP indexes for jumping, trot and gallop races in France, $48^{\text {th }}$ Annual Meeting EAAP, Vienna, Austria (1997)

NEUMAIER, A.; GROENEVELD, E.:

Restricted Maximum Likelihood Estimation of covariances in sparse linear models. Genet. Sel. Evol. 30 (1998), 3-26

SAASTAMOINEN, M.:

Genetic and environmental parameters for measures of racing performance in Standardbred and

Finnhors
SCHMITT, A.:

Das Zuchtprogramm beim Deutschen Traber. Zuchtungskunde, Stuttgart 68 (1996), 81-91

THUNEBERG-SELONEN, T.; PÖSÖ, J.; MÄNTYSAARI, E.; OJALA, M.:

Use of individual race results in the estimation of genetic parameters of trotting performance for WILLMS, F.; ROEHE, R.; KALM; E.:

Genetische Analyse von Merkmalskomplexen in der Reitpferdezucht unter Berilcksichtigung von Gliedmaßenveränderungen. 1. Mitt.: Zilchterische Bedeutung von Gliedmaßenveränderungen. Zuchtungskunde, Stuttgart 71 (1999), 330-345

Received: $2001-08-24$

Accepted: 2001-10-08

Authors' eddresses

PD Dr. RAINER RÖHE, Dr, MOHAMED BRKA,

Prof. Dr. Dr. h. c. mult. ERNST KALM

Institut für Tierzucht und Tierhaltung der Christian-Albrechts-Universiä̈t zu Kiel

Olshausenstr. 40

D-24098 Kiel / Germany

\section{Dr. TUURKER SAVAS}

Abteilung Tierproduktion der Landwirischaftlichen Fakultaet der Canakkale

Onsekiz Mart Üniversitaet,

17100 Canakkale

Turkey

\section{Dr, FRIEDRICH WILLMS}

Hauptverband für Traber-Zucht und -Rennen e. V.

D-41554 Kaarst / Germany 
Arch. Tierz., Dummerstorf 44 (2001) 6, 588

\title{
Buchbesprechung
}

\author{
Lehrbuch der Schweinekrankheiten
}

KARL-HEINZ WALDMANN und MICHAEL WENDT (Hrsg.)

3. durchgesehene Auflage, 604 Seiten, 318 Abbildungen davon 57 farbig, 63 Tabellen, Parey Buchverlag Berlin im Blackwell Wissenschaftsverlag, 2001, DM 175,93; EUR 89,95; ÖS 284,00; SFr 152,00

Das von Hans Plonait und Klaus Bickhardt begrandete Lehrbuch liegt als aktualisierte und durchgesehene 3. Auflage vor. Die Tatsache, dass nach weniger als vier Jahren eine Neuauflage dieses Standardwerkes notwendig wurde, spricht für die große Resonanz dieses Buches und unterstreicht das dringende Bedürfnis aus Wissenschaft und Praxis nach diesem Titel.

Trotz prophylaxeorientierter Schweineproduktion und zunehmenden einschneidenden Regelungen zur Haltung, Medikamentenanwendung, des Tierschutzes und der intensiven Schlachttierbefundung, seben sich der Tierarzt und der Schweinehalter gleichermaßen immer wieder mit Therapienotwendigkeiten konfrontiert. Es ist das Verdienst der Herausgeber einen umfassenden Öberblick uber die wichtigsten Krankheiten des Schweines vorzulegen, der weit aber das Anliegen eines Lehrbuches hinausgeht. Der Inhalt des Buches entspricht weitestgehend dem der 2. Auflage, ein neu aufgenommener Anhang beschreibt neue Krankheitsbilder und lebensmittelrechtliche Hinweise wurden aktualisiert. In den Abschnitten zur Therapie und Prophylaxe der einzelnen Krankheiten wurden die Angaben zur Pharmakotherapie auf den neuesten Stand gebracht.

Im Mittelpunkt des Buches steht das kranke Schwein, in seinem Bestand und sein Krankheitsbild. Davon ausgehend sind diagnostische, therapeutische und prophylaktische Entscheidungen zu freffen. Dem Buchansatz liegt zugrunde, dass Krankheiten an typischen Erscheinungen erkennbar sind und Tierbestände biologische Einheiten bilden. Da sich die Autoren dieses Buches bewusst an einen breiten Leserkreis wenden, haben sie sich um eine verstăndliche, praxisrelevante Darstellungsweise bei der Beschreibung der einzelnen Krankheitsbilder bemuht. Dadurch werden die zugrunde liegenden Vorgänge gut verstundlich und geben Anleitung zum praktischen Handeln. Dieses Buch setzt zwar tierärztliches Wissen voraus, bietet jedoch auch Schweinehaltern wertvolle Informationen, vor allem die Prophylaxe betreffend, ohne den Tierarzt ersetzen zu wollen.

Im ersten allgemeinen Hauptteil werden in vier Kapiteln die Aufgaben des Tierarztes im Selwweinebestand, der Einfluss der Haltungsbedingungen auf das Krankheitsgeschehen, der Umgang des Tierarztes mit Schweinen und die unterschiedlichen therapeutischen Techniken beschrieben. Der spezielle Teil enthalt mit zahlreichen Unterabschnitten die Darstellung folgender Krankheitsgruppen: Hautkrankheiten und Hautveränderungen, fieberhafte Allgemeinerkrankungen mit Virus- und bakteriellen Infektionen, Erkrankungen des Atmungsapparates, des HerzKreislauf-Systems, Blutkrankheiten, Erkrankungen und Storungen des Zentralnervensystems, bakteriell bedingte ZNS-Erkrankungen, Muskelerkrankungen, Gliedmaßen- und Skeletterkrankungen, Erkrankungen der Verdauungsorgane und des Abdomens sowie Erkrankungen der Harnorgane. Weiterhin werden die Fortpflanzungsphysiologie und Gynakologie der Sau, Geburt, Puerperium und perinatale Verluste, Erkrankungen des Gestuges und die Erkrankungen und Operationen an den Fortpflanzungsorganen des Ebers besprochen. Ein letzter Abschnitt ist dem Infektionsschutz, der Sanierung und der planmäßigen Bestandsbehandlung gewidmet. Beí den einzelnen Erkrankungen werden Ätiologie und Pathogenese, klinisches Bild und Verlauf, Diagnose und Differentialdiagnose sowie Therapie und Prophylaxe besprochen. Ein den Krankheiten angefugtes Literaturverzeichnis ermog. licht weitergehende Informationen.

Die detaillierte Gliederung, eine große Anzahl von zum Teil farbigen Abbildungen und aussagekrätige Tabellen tragen wesentlich zum Verstandnis der Textbeschreibungen bei. Dieses sehr praxisrelevante Buch informiert über den neuesten Wissens- und Erkenntnisstand auf diesem Gebiet. Es ist sowohl fir die Aus- und Weiterbildung als auch fir den praktischen Tierarzt und den interessierten Schweinehalter als unentbehrliches Standardwerk sehr zu empfehlen. 